\title{
A Review of the Political Economy of Agriculture in Uganda: Women, Property Rights, and Other Challenges
}

\author{
Dastan Bamwesigye ${ }^{1,3, *}$, Azdren Doli ${ }^{1,3}$, Kyom Jonathan Adamu ${ }^{2,3}$, Sheku Kemoh Mansaray ${ }^{3}$ \\ ${ }^{1}$ Department of Forest and Wood Products Economics and Policy, Mendel University in Brno, Czech Republic \\ ${ }^{2}$ Department of Landscape Management, Mendel University in Brno, Czech Republic \\ ${ }^{3}$ Faculty of Forestry and Wood Technology, Mendel University in Brno, Czech Republic
}

Received July 26, 2019; Revised August 19, 2019; Accepted October 20, 2019

Copyright $\bigcirc 2020$ by authors, all rights reserved. Authors agree that this article remains permanently open access under the terms of the Creative Commons Attribution License 4.0 International License

\begin{abstract}
In Uganda, agriculture remains the backbone of the economy, like in the rest of African countries. The current literature review explores agriculture situations in Uganda while focusing on the role of women, land ownership, and the current policy framework. The authors sought to illustrate some of the core challenges in agriculture and how their impact on agricultural output. The researchers explored various developments in Uganda, such as employment, the role of women, and challenges faced, especially in the aspect related to policy framework as compared to other developing countries such as Ghana, Rwanda, and South Africa. Agricultural production in Uganda is largely dominated by smallholders' farmers, especially those with less than five hectares. These farmers produce a wide range of crops for both consumption and commercial purpose. Challenges such as lack of or limited access to finance, limited access to land, and price fluctuation are discussed. The researchers revealed that there is limited use of agricultural technologies by the farmers.
\end{abstract}

Keywords Agriculture, Challenges, Economy, Employment, Financing, Land, Policy Framework, Smallholder Farmers, Women

\section{Introduction}

Most African economies are thought to highly dependent on Agriculture for Gross Domestic Product earnings as well as food security [1-5]. Agriculture continues to be the core sector in the economic development of Uganda [1]. It is also highlighted that agriculture is essential when it comes to sustainable development as well as poverty reduction in developing countries [6]. In this case, it is not surprising that agricultural production, especially by small-scale farmers in developing countries contributes to the sustainability of food security in both rural and urban population. However, it is worth mentioning that most of the small-scale farmers in developing countries such as Uganda face many challenges related to land, financial support, limited use of technology, and price fluctuation to mention but a few [7-9]. Nonetheless, a wide range of research indicates that agriculture is still considered to be a powerful means in a bid to achieve inclusive development in Uganda [10 -12].

Research shows that more than $60 \%$ of Ugandans are engaged in agriculture [6]. In fact, the sector has always been given priority in the national development plan. Some of the traditional cash crops common in Uganda include coffee, cocoa, and tea to mention but a few [13]. Additionally, other crops include maize, horticulture produce, beans, and soya beans.

In the study conducted by Bamwesigye \& Pomazalova [1], they highlighted that Uganda is among the leading coffee producers and exporters across the globe. They add that coffee earns an average of more than $60 \%$ of agriculture annual export revenue in the country.

Several scholars report that the success of agriculture sector in Uganda depends on several factors, and some of the factors are within the sector while others are general connected to the economy of the country [6]. With the aim of getting to the core of the current situation on agriculture in Uganda, the paper explores various aspects such as employment in agriculture, women in agriculture, challenges, current policy framework, strength and weaknesses are analysed and discussed. 


\section{Literature Review: Situation of Agriculture in Uganda}

Agriculture is considered the backbone of many developing country economies, a common trend similar to Uganda [14, 3]. The Ministry of Agriculture, Animal Industry, and Fisheries associated agriculture with employing $73 \%$ of the population, while contributing $23 \%$ to the gross domestic product of the nation [15]. In this case, Ugandans utilize land through cultivation together with animal breeding to support the nation through sustainable supply of food and supplementary consumable products. In the same light, more research indicates that agriculture is of core value to the economy of Uganda, and the most commonly practiced form, being soil based [16]. In fact, Uganda's agricultural potential is held in high regard as previous studies indicated that the country was the greatest producer of organic products in Africa [17]. However, the ever-growing population threatens food security in the country. Even though the nation's economy continuously grows, food security continues to compromise steady development [18]. Hence, agriculture is of great national importance to Uganda, with the trade undergoing a number of evolutions to better meet the high national demands.

Currently, Uganda produces a variety of agricultural products with coffee, tea, sugar, and livestock as the leading ones [9]. Many researchers indicate that subsistence farming is the most popularly practiced form of agriculture in the country, with over $71 \%$ of the country's farmers practicing it [19]. Also, the situation of agricultural modernization in Uganda is not as intensive would be expected from a nation that largely depends on agriculture, with such inputs occurring relatively small.

Nonetheless, much effort has been placed in enhancing the quality and quantity of produce from lesser productive smallholder farms in Uganda [19]. In fact, owing to sedentary agriculture (it does not include processing of agricultural products from their natural state) as proposed by the government, a $299 \%$ increase in cropland area for Karamoja region was observed by several researchers for the period between 2000 and 2011 [20]. It is also noted that demonstration farms contributed to enhancing agricultural depth of the country through allowing for experimental learning [17]. Finally, recent development, which has greatly improved the financial transactions of farmers in Uganda is Mobile money. In their research investigation, Sekabira and Qaim depict that mobile money services significantly improved smallholder farm household welfare through lowering cash constraints and allowing for long distance transactions [21].

Regarding the exportation of cash crops, the majority of Ugandan agricultural produce does not meet the globally acceptable export safety standard set by most of the western countries. For example, noncertified hot pepper farms in Uganda failed to meet satisfactory European standards by only having basic levels of control and assurance [22]. Consequently, these farms failed to provide information on pesticide microbial contamination alongside their products thus deemed unsatisfactory far as safety standards.

\subsection{Employment in Agriculture}

Most of the rural areas in developing countries depend on agriculture as their main source of income and employment for both men and women [23]. It is not surprising that in 2013, agriculture contributed $72 \%$ to Uganda's GDP [23]. Over two-thirds of agricultural activities in countries like Uganda are usually performed by self-employed people. Most of the jobs that attract wages are mainly found in the processing industry (adding value to the agricultural production). Agriculture and coffee production in particular employ more than five million people doing various jobs [1]. The economic structure of Uganda and other East African countries continue to be dominated by the agriculture sector when it comes to employment. Some of the jobs are at the farm while others are in the post harvesting processes. In this case, youth and women should be encouraged to participate in various activities, which can boost their income; thus, economic development. Furthermore, agricultural salary employment opportunities in Uganda have always existed predominantly only for casual as well as seasonal employees. One of the clear reasons is that agricultural production in Uganda is still seasonal. For most crops such as coffee, there are usually peak season, especially towards harvest times. This creates demand for labor for temporary jobs. However, most of these jobs have no social security and working conditions differ depending on the employer. As research shows, labor supply in the agriculture sector in Uganda is considered to be infinite [6]. Even in rural areas where new employment opportunities are created, the supply remains higher since most people usually migrate into these areas.

One of the core constraints in agricultural sector in rural areas is that the workforce, mostly youth and women lack the required training to engage in high-skill activities [23]. In other words, most people involve in agriculture in Uganda do not have skills, and this continue to push them to the edge as their income remains low [24]. Some of the reasons attributed to this are the low level of education and lack of strong government programs to improve skills among the youth.

\subsection{Women in Agriculture}

In Uganda, women form a large proportion of the agricultural labor force [25], and they play a significant role in the agricultural sector while ensuring that their families have food security [26]. In East Africa, and Uganda in particular, various researchers paint that agriculture continues to be the core driver for labor and 
source of income for most women [6]. Nonetheless, a wide range of research highlight that gender-based inequalities remain as one of the bottlenecks preventing women to thrive in agricultural sector $[6,22,28]$. More so, Zorya et al. [6] suggest that limited or no access to land, control of production as well as lack of financial support are some of the factors that are hindering most women in agriculture. If possible, women should be represented equally in this section

In Uganda, agricultural policies are still inadequate [12]. Kaweesa et al. [12] add that most women in rural areas in Uganda have little or no opportunities for income generation, which makes them depend on subsistence farming [29]. These women still do most of the agricultural work in their households. Men are the ones who benefit or reap much from the final products [30].

Further research shows that small-scale or subsistence agriculture done by women in most parts of Uganda may not even provide enough food for their families [12]. Food security is a problem, especially in most parts of Northern and Eastern regions of Uganda. Improving overall national income in Uganda requires policymakers to support women in agriculture, which could reduce poverty level [12]. On the same note, increasing productivity of women in the agriculture sector can increase agricultural output, which can lower the prices of food in the country. However, this can be done by identifying the core challenges limiting women to engage in agriculture such as funding constraints, limited access to land, and poor agricultural practices among others [26].

\subsection{Challenges in Agriculture in Uganda}

Just like in most of the developing countries, Uganda continues to depend on agriculture for economic development and general livelihood [31]. Based on the fact that the majority of farmers in the country are small-scale producers, most of them have faced a wide range of challenges. More than $90 \%$ of total farm output in most parts of Uganda is produced on land that is less than five hectares [32]. Much as people in Uganda, especially those involved in farming often perceive themselves to be blessed by great nature, the level of agricultural performance continues to be poor compared to most of the neighboring countries such as Kenya. For example, the aggregate output growth in Uganda continues to be weak [33]. In this case, improving small-scale farming and agriculture as a whole requires collective efforts to promote best farm practices, implementation of modern farming system among others [31]. At this point, therefore some of the leading challenges, which must be minimized including the following;

\subsubsection{Limited Access to Land}

Whether a country has abundant or limited land for agriculture, it must be utilized efficiently in order to achieve high outputs [34]. Some of the constraints regarding land use, especially within legal institutions usually affect agricultural productivity [26]. More so, lack of understanding of property rights as well as unreliable security to attract investors remains the core problems as far as land use in Uganda is concerned [31]. According to World Bank, widespread informal land tenure system has continuously limited Uganda's agriculture potential since many farmers cannot use their land as collateral to secure loans [34].

For the past few decades, one of the major challenges that most of the farmers in Uganda faced is limited access to land [35]. Much as access to land is considered to be basic or starting point for farmers, this has always been difficult for women and youth who are engaged in agriculture [26]. In Uganda, land-related customs and laws usually make transfer of land to women and young people challenging, and expensive at the same time. Just like most of the developing countries and especially in Sub-Saharan Africa, land tenure systems including those in Uganda are complex [31]. In this case, this makes it difficult for small-scale farmers to own land.

Most of the land that used to be owned by clans or lineage and communities, especially in rural areas is individualized [26]. As a result, this has limited many families to continue practicing their subsistence farming. In fact, previous findings provide interesting insight claiming that it is unrealistic to think that young people and women who are engaged in agriculture can acquire loans and secure land [36]. In this case, it is very hard for most of these farmers to secure enough capital that can facilitate their small-scale farming.

Furthermore, research shows that limited access to land deters investors in agriculture from making long-term investments such as modern farming [32]. In fact, many people in Uganda have lost their hard-earned money by investing in buying land with fake titles. Nonetheless, farmers in Uganda should be assisted with loans to acquire enough land needed to support their agricultural projects [35]. In this case, therefore, it is worth mentioning that Uganda still has potential to advance its agricultural output, if land policies will be designed to make land easy to acquire thereby helping many farmers including women and the youth to thrive in the agricultural industry.

\subsubsection{Finance Related Challenges}

Just like in most other developing countries, many farmers in Uganda lack the required capital that can help them enhance their agricultural output [37]. In most case, farmers who do not use yield-enhancing inputs such as fertilizers, pesticides or improved seed, usually end up with lower output compare to their counterparts who use them. In this case, therefore, access to finance is one of the core elements to enhance agriculture in a country like Uganda.

In Uganda, inadequate access to finance is among the major challenges affecting farmers across the country. In 
most cases, financial service providers in Uganda give credit or loans to farmers with collateral and insurance. On the same note, it is indicated that access to finance usually favors most farmers who are educated, and with collateral [38]. Smallholder farmers are left out, and this affects agriculture industry. Much as most farmers want loans to boost their agricultural projects because the process and interest rates are very expensive [38]. Most of the commercial banks in Uganda are costly for smallholder farmers as far as securing loans or financial support is concerned. In this case, therefore, it is not surprising that small-scale farmers can be helped through micro-savings institutions available [38]. In other words, the government of Uganda should support farmers financially through their savings and cooperatives.

\subsubsection{Price Fluctuation}

Much as most Ugandans consider agriculture to be the core source of employment opportunities and source of livelihood, price functions in the market remains one of the challenges that limit farmers to sustain their agricultural projects [39]. Some of the agricultural products faced with the problem of price fluctuation include coffee and tea. According to the research, the demand for the supply of most agricultural products, especially coffee is inelastic, and this usually causes significant change in prices [40]. On the same note, due to the inelastic nature of prices of agricultural products, farmers in Uganda just like in most developing countries cannot respond by adjusting their supply overnight [40]. For example, coffee prices in Uganda usually fall, and must farmers make loses that some fail to recover from [24]. In most cases, farmers who acquire agricultural loans without insurance policy usually find themselves in trouble when there is a fall in prices of agricultural products, as some fail to pay back the borrowed money.

Furthermore, weather conditions have always contributed to an increase in prices of most cash crops in Uganda [41]. On the same note, good weather can as well lead to unexpected large increase in output, and this eventually causes price falls in the market. When it comes to agricultural products like maize, New Vision reported that most farmers in Uganda usually cry out when there is a drop-in price [42]. While reporting for the New Vision, Tumwesigye Amos explained that commodity prices in Uganda are unstable to the extent that they can fluctuate from $50 \%$ below to $150 \%$ above the average [42]. In most cases, price fluctuation in most developing countries including Uganda usually weakens the entire supply chain, which in the end creates negative effects such as food insecurity and poverty [39]. In this case, therefore, it is worth mentioning that price functions act as a bottleneck for most farmers who would in one way or the other thrive in their projects. At this point, the government of Uganda and other concerned institutions should work together in supporting farmers, especially smallholders to advance or modernize their project.

\subsubsection{Current Policy Framework}

For many decades, raising agricultural output has always been one of Uganda's development agenda despite the low progress. Much as the country continues to show high potential as far as agriculture is concerned, its progress has remained stagnant for the past few decades. As indicated by Ministry of Agriculture, Animal Industry and Fisheries, Uganda's agriculture policy has always been shaped by a wide range of national policy frameworks [43]. More so, the same research highlights Poverty Eradication Action Plan (PEAP), Prosperity for All (PFA), and National Development Plan (NDP) to mention but a few as some of the contributing frameworks shaping current agriculture policy framework. At agriculture level, Ministry of Agriculture, Animal Industry and Fisheries indicates that these frameworks aim at modernizing agricultural practices in the country [43].

Currently, Uganda's Agriculture Sector Development Strategy and Investment Plan is responsible for ensuring that agricultural policies are implemented across the country [43]. In most cases, the sector usually goes through several ministries and agencies in the process of implementation. Furthermore, the same research highlighted that the current agriculture policy framework, which aims at enhancing the level of output operates under the Ministry of Agriculture. However, there are other several semi-autonomous agencies which are under the same ministry that work hand in hand to ensure the success of agriculture in Uganda. Some of these institutions include National Agricultural Advisory Services (NAADS), Dairy Development Authority (DDA), Cotton Development Organisation (CDO) and Uganda Coffee Development Authority (UCDA) [15].

According to the Ministry of Agriculture, Animal Industry, and Fisheries, this is supposed to be done through coordinated intervention, which aims at enhancing sustainable agricultural output [43]. As a result, create more job opportunities through adding value on the output to attract both domestic and international trade.

As Ministry of Agriculture, Animal Industry, and Fisheries indicates, the government of Uganda pursues the core six inter-related objectives, and each of them with unique strategies in order to achieve desired agriculture policy purpose [43]. For example, the core objectives that guide National Agriculture Plan include; (a) to increase household income through farming, (b) to ensure household food security for all citizens, (c) to ensure sustainable use of available agricultural resources, (d), to promote national and international trade of agricultural products, (e), to develop human resources that can ensure agricultural development, and lastly, (f) to promote specialization in various enterprises that aims at adding value to products through agro-zoning. Based on such background, it is worth mentioning that the government of 
Uganda is working hard to ensure modernization of agriculture despite the quite slow success.

Furthermore, there is no doubt that current Uganda's agriculture policy framework seems to be coherent and clearly planned. However, a wide range of research indicates that poor implementation and high level of corruption that limits its success $[20,36]$. In fact, several of these studies speculate that most of the objectives set by Uganda's government as far as agriculture is concerned are hardly realized. Much as the country has vast potential for agriculture such as availability of land, export markets as well as regional and international advocacy, research shows that output and value addition remain stagnant because of poor implementation and limited knowledge on advanced farming practices [36].

\subsubsection{Policy Comparison}

Uganda's economy is heavily reliant on agriculture thus; a great deal of effort has been placed in ensuring efficient performance of this particular sector. Agriculture remains the underlying driving force in Uganda's economy while assuring employment, food security, and foreign exchange through international trade. Consequently, the Ministry of Agriculture, Animal Industry and Fisheries stated that a lot of attention is scrupulously granted to the sector through the high levels of national planning by the Ugandan Government [44]. As such, the government of Uganda has gone the extra mile to draft strategic plans for the agricultural sector through an extensive agricultural policy. Correspondingly, this effort is fundamentally exerted to the agricultural sectors of other African countries not only Uganda to ensure a profound maximization of returns. In fact, for a multiplicity of African countries, agriculture exists as an essential sector and contributor to GDP, an industry therefore whose rewards are valued in the highest of regard. With the aim of getting to the core of agriculture policies, some of the countries analyzed include Ghana, Rwanda, Botswana, and South Africa. In this way, it is therefore imperative to compare Uganda's current agricultural policies to these mentioned countries to better understand any potential successes or areas for more effort.

In Uganda, the Ministry of Agriculture, Animal Industry and Fisheries stated that the country's agricultural sector is inadequately funded based on public expenditure reviews [44]. In fact, this is true for both public and private agricultural sectors in the country largely resulting from wasteful resources use. More so, the main issue with agricultural funding was that the entirety of the agricultural budget was solicited from projects such as NAADS. Hence, the Development Strategy and Investment Plan (DSIP) was mandated with reforming this issue thus readily availing these constricted funds. However, the Ugandan government set in play agricultural sector investment plans to enhance financial efficiency, seeing growth in budgetary funding for agriculture from $3.8 \%$ in 2008 to $4.5 \%$ in 2012 .

On the other hand, the South African agriculture sector is among the more popularly recognized job creation avenues in the country, alongside fisheries and forestry [45]. Resulting from high job creation potential, food security, and rural development, the government of South Africa formulated policies to support it in better ways. When it comes to funding, however, it is notable that the sector is under-funded, and in fact, the National Treasury's estimates budgeted money allocated to agriculture is only $1.7 \%$ of the total available funds. Likewise, the TRALAC Trade Law Centre further projected a 1.6\% decline of public money allocated to the agricultural budget by 2017 , thus making the sector among the least supported globally [46]. However, the government's agricultural policy was restructured to better financially support this sector while adopting a bottom-up approach.

Furthermore, the Department of Agriculture, Forestry, and Fisheries of South Africa set up a financing system which allowed for the removal of subsidies on interest rates with concerns to agriculture [45]. This was followed by the reduction of agricultural tax for farmers. As opposed to the past, drought was recognized as a normal occurrence thus the government will contribute to drought-resistant technology [47]. Thus, therefore, the high losses incurred through the planting of drought-susceptible crops will be heavily slashed [47]. Equally, the Ghanaian government set in place programs for agriculture as a form of draught support for agricultural products directly affected by draught given the high prevalence of climatic extremes in Ghana.

Agricultural financing in Uganda, has similar problems to that of the Republic of Rwanda as stated by Karanja who called it a challenge for the nation's agricultural sector [48]. Nonetheless, the government of Rwanda has vehemently endeavored to ensure that this issue is purposely dealt with the underlying intention of availing enough funds. Thus, through projects like establishment of the agriculture department at the Development Bank of Rwanda (BRD), remedial solutions have been presented. Moreover, it is the mandate of the BRD to solicit necessary funding to actualize the goal of developing and modernization of agriculture in Rwanda. Ultimately, this was projected to be achieved through agricultural mechanization, development of national agro-processing capacity and financing risk mitigation policies. The ultimate goal is to reach an annual growth rate of $8.5 \%$ for agriculture in the country's Bank and by 2015 BRD accounted for the approval of Rwf. 24 billion to realize this [48].

\subsubsection{Land Ownership}

The land ownership systems in Uganda are complicated, and thus the country has had a history of land grabbing and disputes [32]. The land tenure systems form the basis for land ownership in Uganda, and thus EcoLand (property services in Uganda) acknowledges four types of land tenure systems in Uganda. First, mailo land system, where tenants are governed by their landlords and expected to pay 
rent for the prescribed period of stay [32]. This is strictly commonly limited to central Uganda and the Buganda kingdom. In fact, it is also indicated that crop rotation not popularly practiced on mailo resulting from the insecurity about future access to the land [36]. In most cases, crop rotation usually requires farmers to plant different types of crops on given plot with respect to the prescribed time of stay. Second is the freehold system where land was granted to individuals or institutions with a land title to show full ownership. The land act specifies the fact that this land is exclusively owned by the title owner to do with as they please [49]. Third, the leasehold system offers one with land rights in exchange for the payment of rent to the legal owner of the land for a period from 40 to 90 year. Fourth, the public land tenure. The government owns land, and can lease it to any individual, organization or a company on specific terms. This form of land is for business rather than settlement. The government of Uganda has public land in almost all urban and big towns.

\subsubsection{Rwanda}

In Rwanda, agriculture largely accounts for the country's GDP accounting for about $30 \%$ of the total GDP. And the leading export sector in the country, at the same time, employs over $70 \%$ of the population. Thus, agriculture is considered the commandeering sector for the economy of Rwanda and is, in fact, the leading national provider of foreign exchange.

Republic of Rwanda reported that land ownership systems in the country were of three forms as elaborated herein [50]. First, state land comprised of all public land set aside by and for use to satisfy state needs while also including all land reserved for environmental protection. Hence, the City of Kigali land, roads, public building, wetlands, and national parks are all accounted for here. Second, the private state-owned land is that which is not included in state land, and this accounts for land purchased or donated to the state, land with no ownership and swamps with the capacity for agriculture. Third is Local Government land, and this is public land belonging to the district, municipality and town council, and individually owned land. This entails land acquired by citizens through form of custom or written law, and it is excluding of individual public land or private district land.

\subsubsection{Ghana}

Agriculture in Ghana is commonly practiced on customary lands, a tenure system that has threatened the success of agriculture in the country [51]. Approximately, over $50 \%$ of the population actively engages in agriculture. In fact, it has been an ongoing effort by various regimes in the country to modernize agriculture with the underlying aim of increasing food and cash crop using various agricultural policies [52]. Similar to Uganda, the ultimate authority and ownership over the communal land tenure system fall to traditional authorities or family heads. More so, agriculture in Ghana is constantly under threat stemming from the complexity of the land tenure policy [53]. To elaborate, it is common for a single plot of land to have numerous subdivided plots, and the owner has the rights to sell these plots to different people. As much as this allows many people to own land depending on their levels of income, this has hindered extensive investment in the country.

\subsubsection{Botswana}

According to World Bank report, agriculture in Botswana is largely practiced by traditional sect and on communal land [54]. The contribution of agriculture to the GDP of Botswana was about only $2.1 \%$ in 2017; but it is projected to decrease further in the coming years. Major programs such as Cereal improvement have already been implemented with the aim of boosting crop production and increase contribution to people's income and national food security [54]. However, being the chief driver of the rural economy, the government of Botswana has set in play a number of agricultural policies through the National Policy on Agricultural Development to improve its performance.

The World Bank revealed that two parastatals are largely controlling the marketing of agricultural products in Botswana [54]. These include the Botswana Agricultural Marketing Board (BAMB) and the Botswana Meat Commission (BMC). The BAMB buys grains and beans and proceeds to circulate market prices to be used while supplying these products to depots. Furthermore, it is the directive of BAMB to secure and manage the national strategic grain reserve and selling agricultural inputs to farmers. On the other hand, the BMC manages the livestock sector, thus controls the three major slaughterhouses while guaranteeing continued successful beef export. For example, the local beef market needs are satisfied by private abattoirs and butcheries [54].

The marketing of agricultural products is controlled by the organizations that lead and manage the development of given cash crops such as the Ugandan Coffee Development Authority (UCDA). According to the UCDA, its primary function is to monitor world market price changes and change the price daily to reflect this, while certifying every export deal of the product [55]. Furthermore, marketing of agricultural produce in Uganda has recently adhered to the use of mobile applications to streamline the sector. To elaborate, Sekabira and Qaim said that mobile money services have largely enhanced agricultural welfare through eliminating cash constraints which limited long-distance cash transactions [21]. Similarly, it is presumed that small-scale farmers in Ghana and Uganda used mobile phones for marketing of their products [56].

\section{Discussion}

Based on the findings in this literature review, agriculture is backbone of the economy in Uganda, Ghana, Rwanda, Botswana, and South Africa. In fact, the current 
review revealed that agriculture is the leading economic sector that accounts for large percentage of Uganda' GDP based on the total export $[1,2,3,9]$. It was highlighted that agriculture continues to employ the majority of the population in these countries. In this case, it is not surprising that, the government of Uganda has gone the extra mile to draft strategic plans for the agricultural sector through an extensive agricultural policy. This effort is fundamentally exerted to the agricultural sectors of other mentioned African countries to ensure a profound maximization of returns.

It is important to note that most of the agricultural policies in Uganda, Ghana, Rwanda, Botswana, and South Africa have a huge contribution as far as economic development is concerned. Some of these policies have helped in boosting agriculture sector, and this has reduced poverty and at the same time ensured sustainable environment. In countries studied, agriculture is the core means of livelihood, and better policies act as great instrument for development. As much as a wide range of research revealed that Uganda, Rwanda, Ghana, and South Africa are improving their agricultural policies, the productivity remains low, especially in Uganda.

Nonetheless, the current review indicates that through comprehensive policies, the Department of Agriculture, Forestry, and Fisheries of South Africa has improved agriculture by setting up a financing system to boost the sector. In Ghana, the government set in place programs for agriculture as a form of drought support for agricultural products directly affected by drought given the high prevalence of climatic extremes in Ghana. It is worth mentioning that such policies in the agriculture sector aim at modernizing farming in one way or the other, and countries like Uganda, Rwanda, and Ghana are working hard despite the slow progress.

Based on the finding of the current review, improving overall national income in Uganda, Ghana, Rwanda, and South Africa requires policymakers to support agricultural programs. On the same note, increasing productivity of women in the agriculture sector can increase agricultural output, which can as well lower the prices of food in the country. However, this can be done by identifying the core challenges limiting farmers, especially women to engage in agriculture. Some of the challenges that have been highlighted include funding constraints, limited access to land, poor agricultural practices to mention but a few. In this perspective, finding solutions for these challenges that most farmers face could harness their potential in the agricultural sector in these counties.

\section{Conclusions}

In relation to the research findings, the current review has reached various conclusions. First, the review revealed that in Uganda, agricultural production is still largely undertaken by smallholders, especially those with less than five hectares. These farmers produce a wide range of crops for both consumption, and commercial and or household livelihood. Because of poverty level and various challenges associated with agriculture in Uganda, farm mechanization, and implementation of advanced practices to enhance inputs, were found to be low in Uganda. Furthermore, the current review revealed that there are many challenges that contribute to low farm productivity. Some of these challenges include lack of or limited access to finance, limited access to land, price fluctuation and corruption that leads to misallocation of resources. More so, other factors highlighted that were believed to be bottlenecks to agricultural productivity include poor government support system to farmers.

Second, it was revealed that there is undeniable limited use of agricultural technologies by the farmers in the country. In fact, lack of such fundamental investment has crippled the quality and quantity of agricultural produce from Uganda thus leading to agricultural unproductivity. On the same note, one of the fundamental reasons behind this is believed to be high level of counterfeit products sold on the Ugandan market. For example, there have been cases of fake pesticides, fertilizers banned materials which when exposed to farmlands destroy crops while harming human health. In this case, the government of Uganda needs to investigate such cases and deal with them amicably.

Based on the agriculture situation in Uganda, there are various ways government policies can help improve agricultural output. For example, the government of Uganda should establish resource support for farmers, especially smallholders. As stated in this research, one of the major challenges faced by farmers is lack of enough capital to facilitate modern agriculture. At this point, effective resource allocation, which can be done through structural adjustment, can help enhance agricultural output. Still, on access to finance, there is a need to improve the level resources accessed by smallholders. The government of Uganda can do this through providing low-interest loans.

On land, given the fact that most of the farmland in rural areas are not registered, the government should make the registration flexible to allow many people to process formal land documentation which bring about the advantages of property rights. Nonetheless, improving agricultural output in Uganda requires collective efforts to promote best farm practices, implementation of modern farming, and this can be done through establishment of better agricultural policies.

\section{REFERENCES}

[1] Bamwesigye, D., and Pomazalova, N. 2015. Assessment of 
the Economic Effects of Liberalization of Coffee Sector in Uganda. MendelNet 2015, Proceedings, 289--294. ISBN 978-80-7509-363-9.

[2] Verter, N., and Bečvářová, V. 2014. Drivers of cocoa export in Ghana in the era of free trade. World Applied Sciences Journal, 32 (8): 1710-1716.

[3] Bamwesigye, D., Hlavackova, P. 2019. An Analysis of Social Ties: Coffee Value Chain in Uganda. Journal of Arts, Science \& Commerce. DOI: 10.18843/rwjasc/v10i1/04

[4] Verter N, Bamwesigye D., Darkwah S, A. 2015. Analysis of Coffee Production and Exports in Uganda. International Conference on Applied Business Research, Madrid, Mendel University in Brno, 2015.640--647. ISBN 978-80-7509-37 9-0.

[5] Verter, N., Bečvářová. V. 2016. The impact of agricultural exports on economic growth in Nigeria. Acta Universitatis Agriculturae et Silviculturae Mendelianae Brunensis 64 (2): 691-700.

[6] Zorya Sergiy, Varun Kshirsagar, Madhur Gautam, Odwongo Willy, and Rachel Sebudde. 2012. Agriculture for Inclusive Growth in Uganda. doi:10.1596/27436

[7] Jayne, T, S., David Mather, D., Mghenyi. E. 2010. Principal challenges confronting smallholder agriculture in sub-Saharan Africa. World development 38(10): 13841398.

[8] Pretty, J., Toulmin, C., Williams, S. 2011. Sustainable intensification in African agriculture. International journal of agricultural sustainability, 9(1), 5-24. https://doi.org/10. 3763/ijas.2010.0583

[9] Owach, C., Bahiigwa G., Elepu G. 2017. Farming household food storage, consumption and sales decision making under price risk in northern Uganda. Journal of Development and Agricultural Economics, 9(1), 8-15. doi:10.5897/jdae2016. 0778

[10] Templer, N., Hauser, M., Owamani, A,, Kamusingize, D., Probst, L. 2018. Does certified organic agriculture increase agroecosystem health? Evidence from four farming systems in Uganda. International Journal of Agricultural Sustainability, 16(2), 150-166. doi:10.1080/14735903.201 8.1440465

[11] Sabiiti, G., Mwalichi, J, I., Ayieko, 1, O., Ouma, L., Artan, G., Basalirwa, C et al. 2017. Adapting Agriculture to Climate Change: Suitability of Banana Crop Production to Future Climate Change over Uganda. Climate Change Management, 175-190. doi:10.1007/978-3-319-64599-5_1 0

[12] Kaweesa, S., Mkomwa S., Loiskandl, W. 2018. Adoption of Conservation Agriculture in Uganda: A Case Study of the Lango Subregion. Sustainability, 10(10), 3375. doi:10.339 0/su10103375

[13] Latynskiy, E., Berger, T. 2016. Networks of Rural Producer Organizations in Uganda: What Can be Done to Make Them Work Better? World Development, 78, 572-586. doi:10.1016/j.worlddev.2015.10.014

[14] Kwapong, N, A., Nkonya, E. 2015. Agriculture extension reforms and development in Uganda. Journal of
Agriculture Extension and Rural Development, 7(4), 122-134. Retrieved from https://academicjournals.org/jour nal/JAERD/article-full-text-pdf/FD94D4851880

[15] Ministry of Agriculture, Animal Industry and Fisheries. 2016. Agriculture Sector Strategic Plan 2015/16-2019/20. Retrieved from http://npa.ug/wp-content/uploads/2016/08/ ASSP-Final-Draft.pdf

[16] Owaraga, N. 2016. Agriculture in Uganda. CPAR Uganda. Retrieved from www.cparuganda.com

[17] Hauser, M., Lindtner, M. 2016. Organic agriculture in post-war Uganda: emergence of pioneer-led niches between 1986 and 1993. Renewable Agriculture and Food Systems, 32(02), 169-178. doi:10.1017/s1742170516000132

[18] Wichern, J, Van Wijk, M., Descheemaeker, K., Frelat, R., Van Asten, P., Giller, K. 2017. Food availability and livelihood strategies among rural households across Uganda. Food Security, 9(6), 1385-1403. doi:10.1007/s12571-0170732-9

[19] Pan, Y., Smith, S, Sulaiman, S. 2018. Agricultural Extension and Technology Adoption for Food Security: Evidence from Uganda. American Journal of Agricultural Economics, 100(4), 1012-1031. doi:10.1093/ajae/aay012

[20] Nakalembe, C., Dempewolf, J., Justice, C. 2017. Agricultural land use change in Karamoja Region, Uganda. Land Use Policy, 62, 2-12. doi:10.1016/j.landusepol.2016. 11.029

[21] Sekabira, H., Qaim, M. 2017. Mobile money, agricultural marketing, and off-farm income in Uganda. Agricultural Economics, 48(5), 597-611. doi:10.1111/agec.12360

[22] Nanyunja, J., Jacxsens, L., Van Boxstael, S, J., Pieternel D, L., Uyttendaele, M. 2015. Assessing the Status of Food Safety Management Systems for Fresh Produce Production in East Africa: Evidence from Certified Green Bean Farms in Kenya and Noncertified Hot Pepper Farms in Uganda. Journal of Food Protection, 78(6), 1081-1089. doi: 10.431 5/0362-028x.jfp-14-364

[23] Nolte, K, Ostermeier, M. 2017. Labour Market Effects of Large-Scale Agricultural Investment: Conceptual Considerations and Estimated Employment Effects. World Development, 98, 430-446. doi:10.1016/j.worlddev.2017.0 5.012

[24] Kwapong, N, A. 2013. Restructured Agricultural Cooperative Marketing System in Uganda: A Study of the 'Tripartite Cooperative Model'. SSRN Electronic Journal. doi:10.2139/ssrn.2312314

[25] Ali, D., Bowen, F., Deininger, K., Duponchel, M. 2015. Investigating the Gender Gap in Agricultural Productivity: Evidence from Uganda. Policy Research Working Papers. doi:10.1596/1813-9450-7262

[26] Chigbu, U. E., Paradza, G., Dachaga, W. 2019. Differentiations in Women's Land Tenure Experiences: Implications for Women's Land Access and Tenure Security in Sub-Saharan Africa. Land, 8(2), 22. doi:10.3390/land 8020022

[27] World Bank. 2018. Making Farming More Productive and Profitable for Ugandan Farmers. Retrieved from https://www.worldbank.org/en/country/uganda/publication 
/making-farming-more-productive-and-profitable-for-ugan dan-farmers

[28] Thornton, P., Kristjanson, P., Förch, W, Barahona, C., Cramer, L, Pradhan, S. 2018. Is agricultural adaptation to global change in lower-income countries on track to meet the future food production challenge? Global Environmental Change, 52, 37-48. doi:10.1016/j.gloenvch a.2018.06.003

[29] Ali, D., Frederick, B., Klaus, D., Marguerite D. 2016. Investigating the Gender Gap in Agricultural Productivity: Evidence from Uganda. World Development, 87, 152-170. doi:10.1016/j.worlddev.2016.06.006

[30] De la O Campos, A. P., Covarrubias, K. A., Prieto Patron, A. 2016. How Does the Choice of the Gender Indicator Affect the Analysis of Gender Differences in Agricultural Productivity? Evidence from Uganda. World Development, 77, 17-33. doi:10.1016/j.worlddev.2015.08.008

[31] Deininger, K., Savastano, S. and Xia, F., 2017. Smallholders' land access in Sub-Saharan Africa: A new landscape? Food Policy, 67, 78-92. doi:10.1016/j.foodpol.2016.09.012

[32] Byamugisha, F. 2014. Land Reform and Investments in Agriculture for Socio-Economic Transformation of Uganda. National Development Policy Forum. National Planning Authority, (1). Retrieved from npa.ug

[33] Mukoki, J. 2018. Constraints of Fertilizer Use among Small Scale Farmers in Uganda: A Case of Kawanda and Namulonge Farmers in Wakiso District. SSRN Electronic Journal. doi:10.2139/ssrn.3176574

[34] World Bank. 2015. Can Uganda's land support its prosperity drive? World Bank Report No 99060. Washington DC: World Bank

[35] Mbasabye, E. 2018. Modernizing Agriculture is a Big Challenge? Bank of Uganda. Retrieved from http://earthfinds.co.ug/index.php/features/opinion/item/418 -modernizing-agriculture-is-a-big-challenge-bank-of-ugan da

[36] Kyomugisha, E. 2014. Land tenure and agricultural productivity in Uganda. International Food Policy Research Institute, (5). Retrieved from www.ifpri.org/

[37] International Food Policy Research Institute. 2012. Rural-Urban Transformation in Uganda. Working Paper. Retrieved from http://www.ifpri.org/sites/default/files/publ ications/usspwp10.pdf

[38] Ogang, C. 2017. Challenges of Agricultural Financing: the Case of Uganda. Retrieved from http://www.wfo-oma.org/ women-in-agriculture/case-studies/challenges-of-agricultur al-financing-the-case-of-uganda.html

[39] Yamano, T., Arai, A. 2011. The Maize Farm-Market Price Spread in Kenya and Uganda. Emerging Development of Agriculture in East Africa, 23-38. doi:10.1007/978-94-007 $-1201-0 \_2$

[40] Bussolo, M., Godart, O., Lay, J., Thiele R. 2007. The impact of coffee price changes on rural households in Uganda.

Agricultural Economics, 37(2-3), 293-303. doi:10.1111/j.1 574-0862.2007.00275.x
[41] Pettinger, T. 2017. What causes price fluctuations in agricultural markets? - Economics Help. Retrieved from https://www.economicshelp.org/blog/23840/economics/wh at-causes-price-fluctuations-in-agricultural-markets/

[42] New Vision. 2010, February 28. Price fluctuations big risk. Tumwesigye Amos[Kampala]. Retrieved fromhttps://www. newvision.co.ug/new_vision/news/1295078/price-fluctuati ons-risk

[43] Ministry of Agriculture, Animal Industry \& Fisheries. 2017. National Strategy for Youth Employment in Agriculture. Retrieved from http://www.scan.ug/edward/NATIONAL STRATEGY FOR YOUTH EMPLOYMENT IN AGRI CULTURE_(NSYEA)_FINĀL-2017.pdf

[44] Ministry of Agriculture, Animal Industry and Fisheries. 2014. National Agricultural Policy. Retrieved from Ministry of Agriculture, Animal Industry and Fisheries website: agriculture.go.ug/

[45] Department of Agriculture, Forestry and Fisheries. 2014. Agricultural Policy Action Plan. Department of Agriculture, Forestry and Fisheries. Republic of South Africa. Retrieved from https://www.daff.gov.za/

[46] TRALAC Trade Law Centre. 2015. South Africa publishes Agricultural Policy Action Plan (APAP) 2015-2019. Retrieved from https://www.tralac.org/news/article/8095-s outh-africa-publishes-agricultural-policy-action-plan-apap2015-2019.html

[47] Nhamo, L., Mathcaya, G., Mabhaudhi, T., Nhlengethwa, S., Nhemachena, C, Mpandeli, S. 2019. Cereal Production Trends under Climate Change: Impacts and Adaptation Strategies in Southern Africa. Agriculture, 9(2), 30. Retrieved from https://www.mdpi.com/2077-0472/9/2/30

[48] Karanja, M. 2017. Agriculture financing key to boost Rwanda's economy. Retrieved from https://www.newtimes .co.rw/section/read/217233

[49] Tatwangire A, Holden, S. 2014. Land Tenure Reforms, Land Market Participation and the Farm Size Productivity Relationship in Uganda. Land Tenure Reform in Asia and Africa, 187-210. doi:10.1057/9781137343819 8

[50] Republic of Rwanda. 2015. Land Tenure in Rwanda. Retrieved from Republic of Rwanda website: http://fortune ofafrica.com/

[51] Frimpong, R. 2018. Land Tenure system; a threat to Ghana's

Agricultural sector. Retrieved from https://www.gardja.org /land-tenure-system-threat-ghanas-agricultural-sector/

[52] Jotie, S. 2015. Ghana's Agric Policy since 1960. Planting for Food and Jobs the new baby - Government of Ghana. Retrieved from Government of Ghana website: http://www .ghana.gov.gh

[53] Shem, S. 2018. Customary land tenure system in Ghana and its problems. Retrieved from https://yen.com.gh/111693-cu stomary-land-tenure-system-ghana-problems.html\#111693

[54] World Bank. 2014. Agriculture Public Expenditure Review, 2000-2013, Botswana. Retrieved from World Bank website: www.worldbank.org/afr/agperprogram

[55] Uganda Coffee Development Authority. 2015. Functions of 
UCDA | Uganda Coffee Development Authority. Retrieved from Uganda Coffee Development Authority website: https://ugandacoffee.go.ug/functions-ucda

[56] Jarkko, N., Nicholas, M, Mila, S. 2015. Use of mobile phones in agricultural marketing in Ghana and Uganda. International Food Policy Research Institute. 